GEOLOGICAL SURVEY CIRCULAR 534

\title{
Gold Geochemical Anomaly in the Cortez District Nevada
}

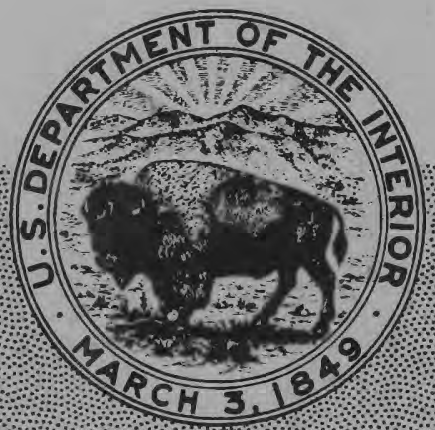




\section{Gold Geochemical Anomaly in the Cortez District Nevada}

By R. L. Erickson, G. H. Van Sickle, H. M. Nakagawa, J. H. McCarthy, Jr., and K. W. Leong

GEOLOGICAL SURVEY CIRCULAR 534

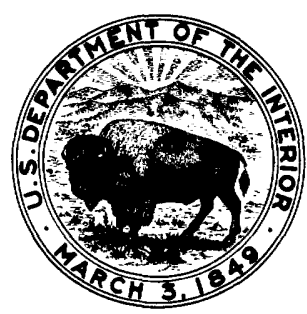


United States Department of the Interior

STEWART L. UDALL, Secretary

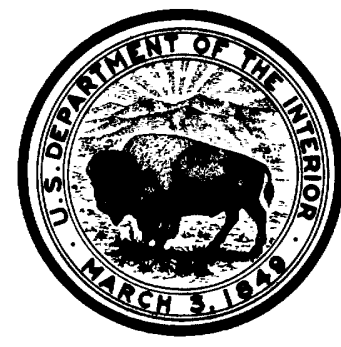

Geological Survey

William T. Pecora; Director

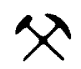

First printing 1966

Second printing 1968 


\title{
Gold geochemical anomaly in the Cortez district, Nevada
}

\author{
By R. L. Erickson, G. H. Van Sickle, H. M. Nakagawa, J. H. McCarthy, Jr., and K. W. Leong
}

\begin{abstract}
An area in the Cortez district, Nevada, previously established to be anomalous in arsenic, antimony, and tungsten has been found to be anomalous also in mercury and gold. Samples from narrow quartz veins, calcite veins, and shear zones in partially silicified limestone in the lower plate of the Roberts thrust fault (Cortez window) contain as much as 3.4 ounces gold per ton. The richest samples are from an outcrop, about 100 feet long, surrounded by gravels. Their economic significance is yet to be established.
\end{abstract}

\section{INTRODUCTION}

The geochemical association of arsenic, mercury, antimony, and tungsten with gold has been recognized at several low-grade open-pit mines-such as Getchell, Bootstrap, Carlin, and Gold Acres mines-in northcentral Nevada (Erickson and others, 1964b; Engineering and Mining Journal, 1966). Geochemical prospecting in the Cortez district revealed anomalous amounts of arsenic, antimony, and tungsten and led to analysis of samples for mercury and gold. Development by Lakin and Nakagawa (1965) of a sensitive chemical method for rapid determination of gold in rocks and soils and by Vaughn and McCarthy (1964) of a mercury sniffer made such analysis possible in the field during geochemical prospecting.

The Carlin and Bootstrap mines in the Tuscarora Mountains, Elko and Eureka Counties, and the Gold Acres mine in the Shoshone Range, Lander County, are associated with windows in the Roberts thrust, a major structural feature of north-central Nevada along which a number of mining districts are situated (Roberts, 1960). Gold ore is chiefly in the thrust zone at Bootstrap and Gold Acres and is in and below the thrust zone at Carlin (Peter N. Lancar, Newmont's Carlin gold mine: Soc. Mining Engineers Fall Mtg. Rocky Mtn. Minerals Conf., Phoenix, Ariz., Oct. 1965). At the Getchell mine in the Osgood Mountains, Humboldt County, gold occurs in the high-angle Getchell fault zone, a zone that appears unrelated to the Roberts thrust (Hotz and Willden, 1964).

In early 1966 surface-rock and drill-hole samples collected in previous geochemical studies in the Cortez district were analyzed for gold by Nakagawa, using both chemical and atomic-absorption methods. Anom- alous amounts of gold-5-14 ppm (parts per million), equivalent to $0.145-0.41$ ounce per ton-were found in two surface rock samples; $2-8 \mathrm{ppm}(0.06-0.23$ oz per ton) gold was found in heavy-mineral concentrates of rotary-drill cuttings from two shallow holes drilled near the boundary of an arsenic-antimony-tungsten anomaly. These results prompted additional fieldwork in May 1966, which is reported here.

Analyses of newly collected samples showed gold concentrations as high as 3.4 ounces per ton. The samples are from narrow quartz veins, calcite veins, and shear zones in partially silicified limestone of Silurian and Devonian age in the lower plate of the Roberts thrust (Cortez window) near the Crescent fault about 4 miles north of Cortez, Nev. (fig. 1). The highest gold assays discovered in this investigation occur in samples from an outcrop, about 100 feet long, consisting of altered Devonian limestone near the east end of an arsenic-antimony-tungsten ge o ch e mical anomaly previously reported by Erickson, Masursky, Marranzino, Oda, and Janes (1964a).

The geology of the Cortez quadrangle is described by Gilluly and Masursky (1965), and the reader is referred to their report and to reports on the geochemical investigations (Erickson and others, 1961, 1964a) for a more complete discussion of the geology and geochemistry of the area.

Elwin Mosier, Howard Knight, Arthur Hubert, and Theodore Roemer, all of the U.S. Geological Survey, participated with the authors in this short but intensive field study.

\section{RESULTS OF INVESTIGATION}

For this investigation 238 rock samples were collected from 95 localities near the Crescent fault about 4 miles north of Cortez (fig. 1). Analytical results (table 1) are given only for those samples that, by at least one analytical method, cont a in significant amounts of gold $(0.3 \mathrm{ppm}$, or 0.09 oz per ton). To check the gold values determin ed by colorimetric and atomicabsorption methods, 27 samples were analyzed by fire assay by C. O. Parker and Co., Denver, Colo. The results show good agreement (table 1) in view of the fact that only 1-and 2-gram s a mples were used in the colorimetric and atomic-absorption methods. Sample localities and localities with significant amounts of 
gold are shown in figure 1. Sample localities and areas of anomalous concentrations of arsenic, antimony, tungsten, and mercury are shown in figures $2,3,4$, and 5 , respectively.

The highest gold assays were found in samples from locality 722 (fig. 1), an exposure of altered limestone that, as previously mentioned, is east of the area of the strong ar senic-antimony-tungsten anomaly. The limestone, which forms a dip slope on the east side of a ridge, strikes $\mathrm{N}_{.} 5^{\circ} \mathrm{E}$., dips $65^{\circ} \mathrm{E}$., and is exposed for about 100 feet along strike. The base of the slope is covered by talus. The limestone is dark or ange brown in overall appearance and contains nearly vertical white calcite veins and calcite-cemented breccia zones as much as 10 inches wide that strike westward into the ridge. Quartz stringers up to 2 inches wide are parallel or subparallel to a brick-red shear zone, 8 inches wide, that strikes $\mathrm{N}$. $75^{\circ} \mathrm{W}$. and dips $30^{\circ} \mathrm{SW}$. Samples 722 through $722-\mathrm{K}$ (table 1) are selected samples from the talus; all others are from narrow veins and shear zones in the limestone. All veins, shear zones, breccia zones, and fractures sampled at this locality are gold bearing. The type of material probably constitutes less than 10 percent of the outcrop area. We have no data at present on the gold content of limestone that is not sheared, brecciated, or veined.

Dark-brownish-black jasperoid masses that crop out discontinuously on the west side of the ridge above locality 722 (fig. 1, table 1) contain much smaller but nonetheless anomalous amounts of gold. Gravel deposits cover the area between these jasperoid masses and locality 722 and may conceal gold-bearing altered rocks.

At sample localities $601,600,700,701$, and 702 (fig. 1), a conspicuous brick-red breccia zone, about 8 feet wide, in skarn and altered limestone strikes N. $10^{\circ} \mathrm{W}$. and dips steeply east. Gold was detected only at locality 600 and in only 2 of 21 samples collected there.

At locality 606 gold occurs in a zone of dark-maroon jasperoid and breccia that contains white calcite pods and stringers. No attempt was made to trace this jasperoid zone along strike.

Preliminary mineralogic work on one sample (722-D) suggests that most of the gold occurs as very tiny disseminated specks and fine lacework in oxidized pyrite crystals. The largest fragment of gold ubserved in this sample is only a few microns thick but measures 200 microns in largest dimension.

The silver content of allgold-bea $\mathrm{r}$ ing samples is very low (maximum assay, 0.16 oz per ton). Spectrographic analyses show that arsenic is the most abundant metal in the gold-bearing samples; arsenic and mercury contents show a direct correlation with gold content. Small amounts of antimony and tungsten may be present; although antimony and tungsten contents do not show a direct correlation with gold content, anomalously high concentrations of antimony and tungsten commonly occur in rocks in or adjacent to areas of gold mineralization. Lead, zinc, and copper are not present in significant amounts.

An entirely different suite of metals was detected at locality 7.59 (fig. 1). Here, a light-gray, pink-weathering fine-grained limestone with finely disseminated oxidized pyrite crystals contains 5,000 ppm zinc, 300 ppm copper, and $20 \mathrm{ppm}$ bismuth. A thin white pyritic quartz veinlet cutting the limestone contains $3,000 \mathrm{ppm}$ zinc, 500 ppm copper, 300 ppm lead, 70 ppm tin, 200 ppm bismuth, and 200 ppm antimony. Gold was not detected in these samples.

Caliche-cemented gravel was sampled at 12 localities (fig. 1) in the search for possibleplacer accumulations of gold. Gold content was below the limit of detection $(0.1 \mathrm{ppm})$ in all samples.

\section{REFERENCES CITED}

Engineering and Mining Journal, 1966, Exploration. . . A study in ingenuity: Eng. Mining Jour., 167, 6. p. 200 .

Erickson, R. L., Masursky, Harold, Marranzino, A. P., and Oda, Uteana, 1961, Geochemical anomalies in the upper plate of the Roberts thrust near Cortez, Nevada, in Short papers in the geologic and hydrologic sciences: U.S. Geol. Survey Prof. P aper 424-D, p. D316-D320.

Erickson, R. L., Masursky, Harold, Marranzino, A. P., Oda, Uteana, and Janes, W. W., 1964a, Geochemical anomalies in the lower plate of the Roberts thrust, near Cortez. Nevada, in Geological Survey Research 1964: U.S. Geol. Survey Prof. Paper $501-\mathrm{B}, \mathrm{p} . \mathrm{B} 92-\mathrm{B} 94$.

Erickson, R. L., Marranzino, A. P., Oda, Uteana, and Janes, W. W., 1964b, G e oc he m i c a 1 exploration near the Getchell mine, Humboldt County, Nevada: U.S. Geol. Survey Bull. 1198-A, 26 p.

Gilluly, James, and Masursky, Harold, 1965, Geology of the Cortez quadrangle, Nevada: U.S. Geol. Survey Bull. $1175,117 \mathrm{p}$.

Hotz, P. E., and Willden, C. R., 1964, Geology and mineral deposits of the Osgood Mountains quadrangle, Humboldt County, Nevada: U.S. Geol. Survey Prof. Paper 431. 128 p.

Lakin, H. W.. and Nakagawa, H. M., 1965, A spectrophotometric method for the determination of traces of gold in geologic materials, in Geological Survey Research 1965: U.S. Geol. Survey Prof. Paper 52.5-C, p. C168-C171.

Roberts, R. J., 1960, Alinement of mining districts in north central Nevada, in Geological Survey Research 1960: U.S. Geol. Survey Prof. Paper 400-B, p. B17-B19.

Vaughn, W. W., and McCarthy, J. H., Jr., 1964, An instrumental technique for the determination of submicrogram concentrations of mercury in soils, rocks, and gas, in Geological Survey Research 1964: U.S. Geol. Survey P rof. P a per 501-D. p. D123-D127. 
Table 1.--Analyses of rocks from the lower plate of the Roberts thrust, Cortez window, Nevada. [Spectrographic analyses Dy Elwin Mosier; colorimetric analyses for gold by G. H. Van Sickle; atomicabsorption analyses for gold by H. M. Nakagawa, G. H. Van Sickle, K. W. Leong, and Arthur Hubert; and for mercury by W. W. Janes and J. H. McCarthy, Jr.; fire-assay analyses by Charles O. Parker and Co. tr., trace; n.d., not determined. Sample localities shown in fig. 1. Multiple samples from one locality indicated by letter suffix.]

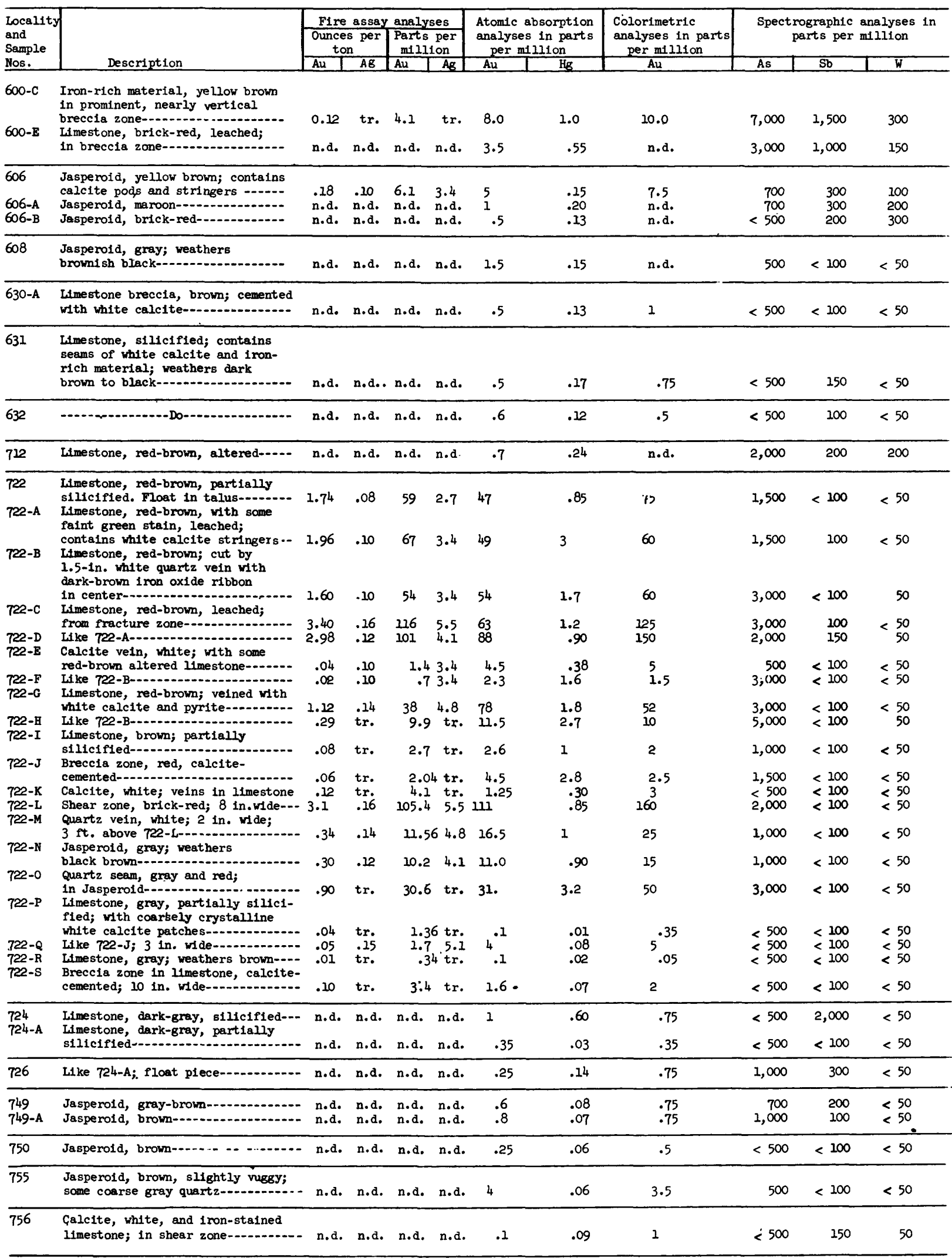




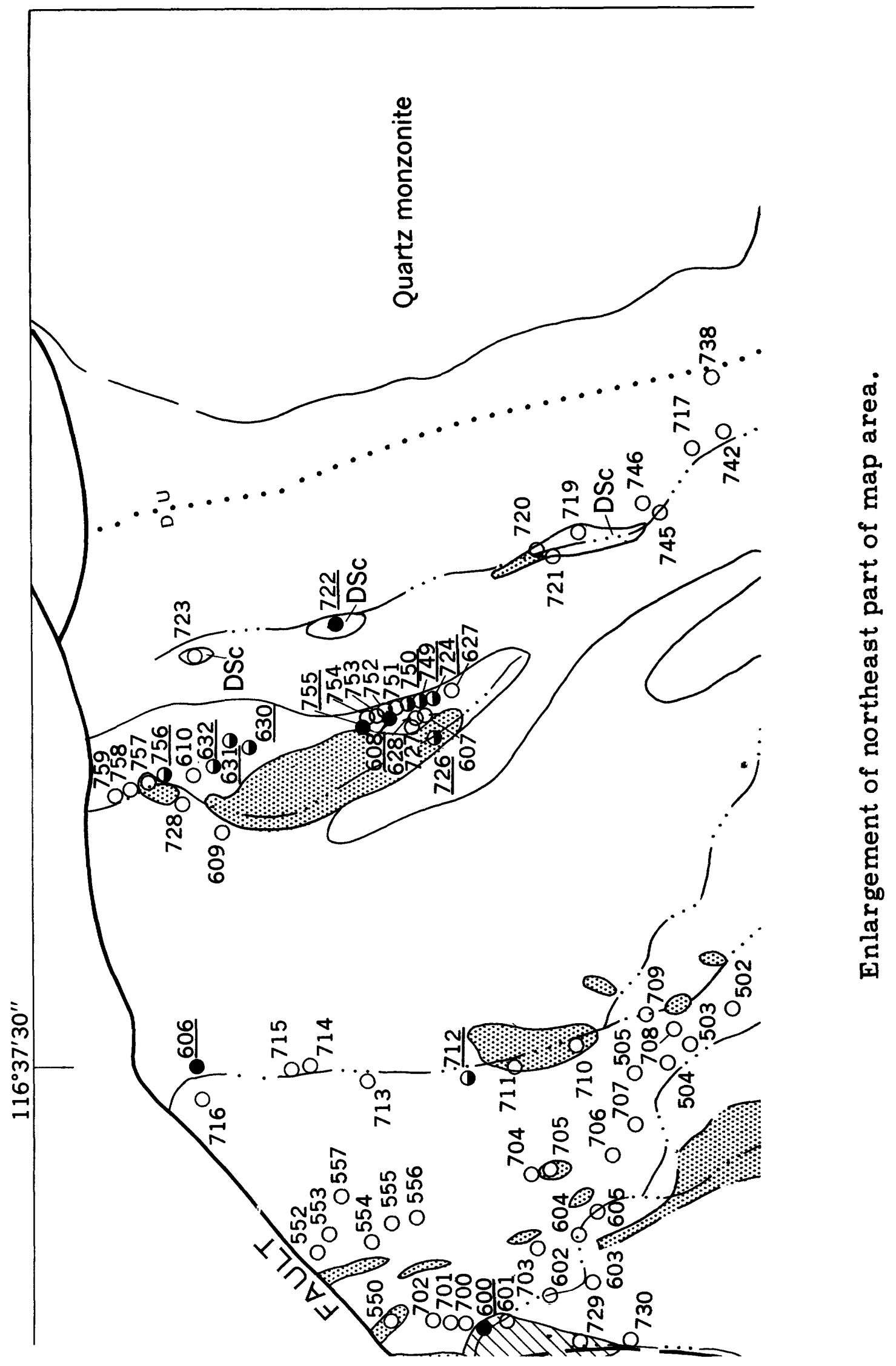




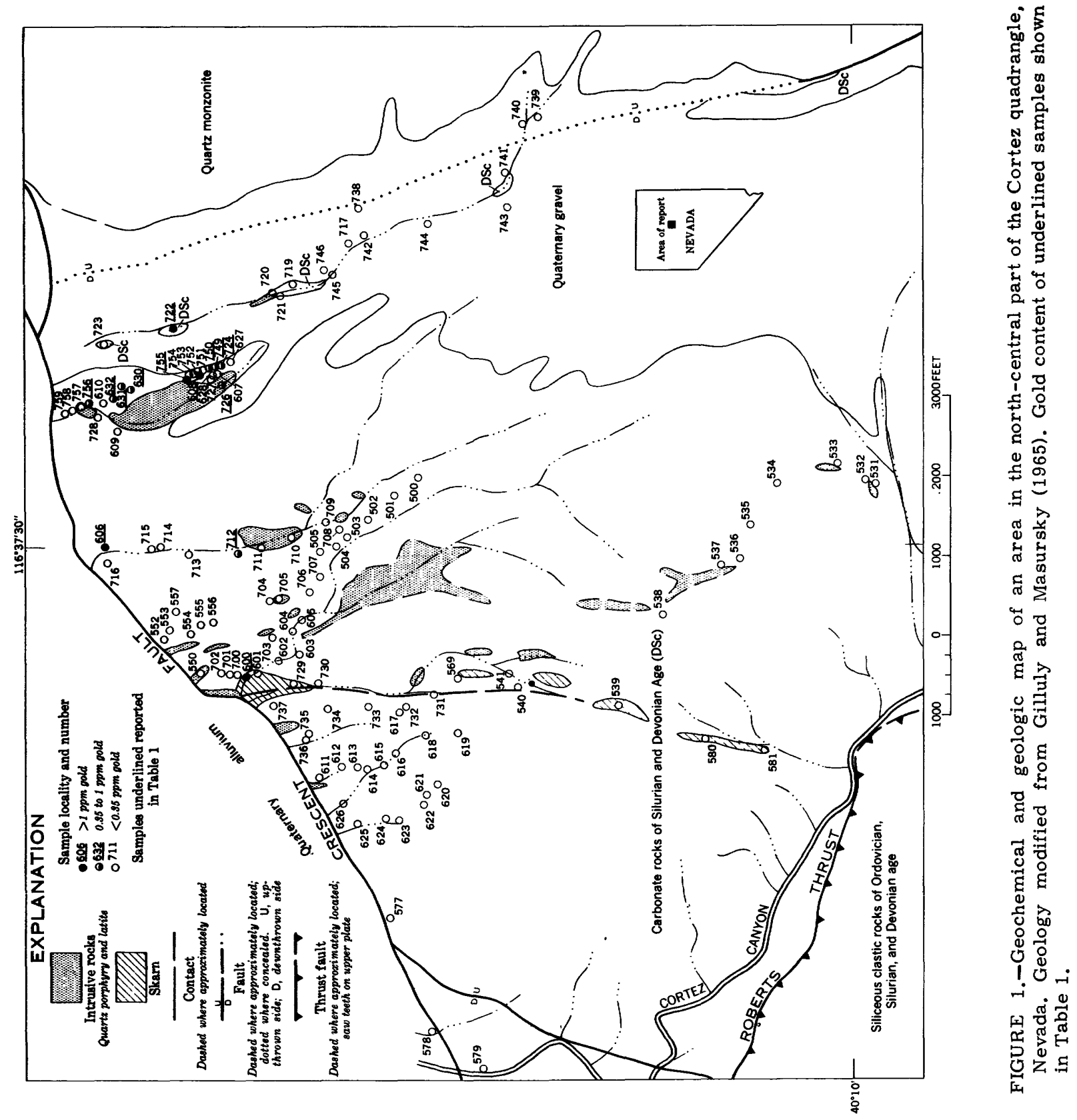




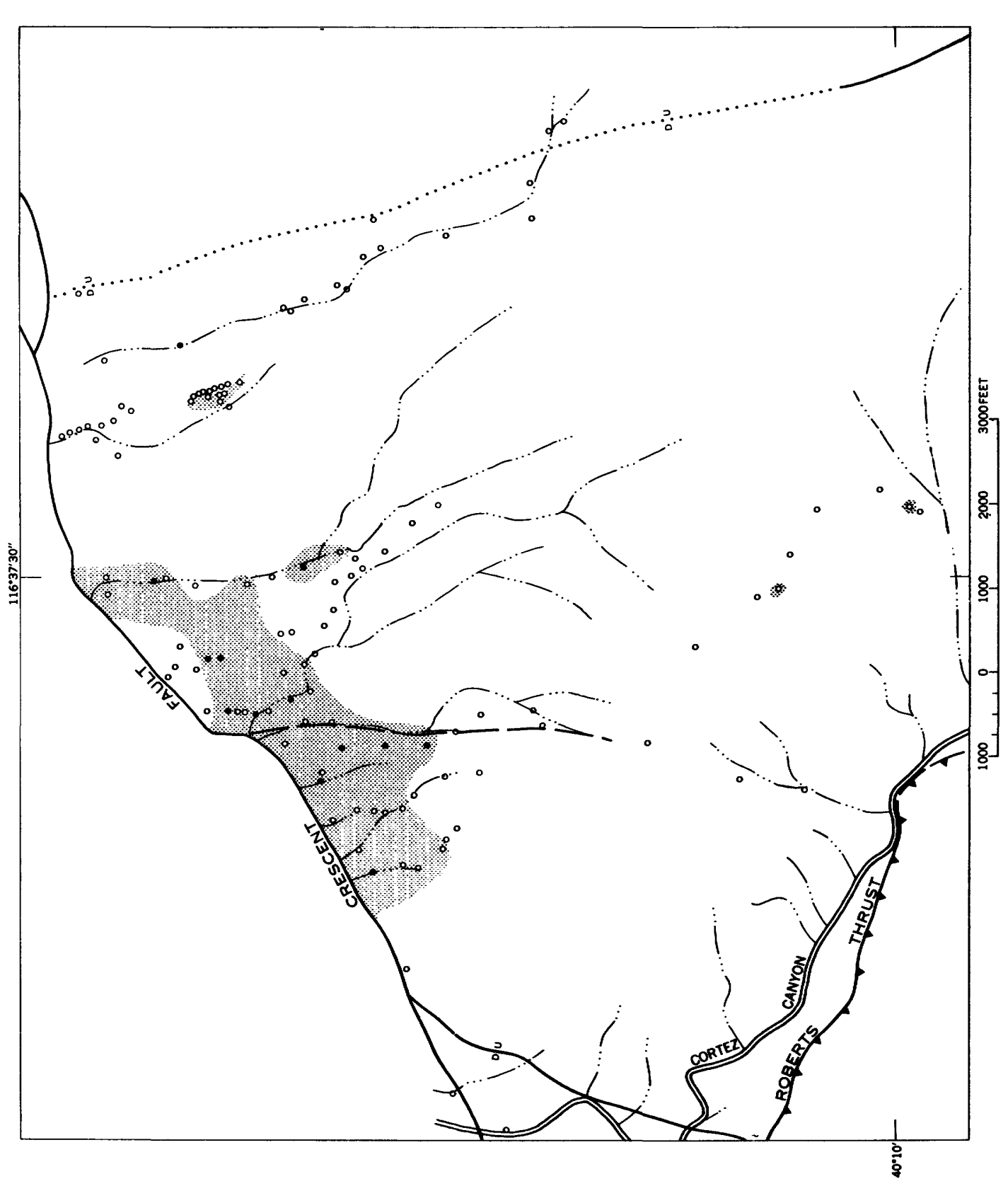

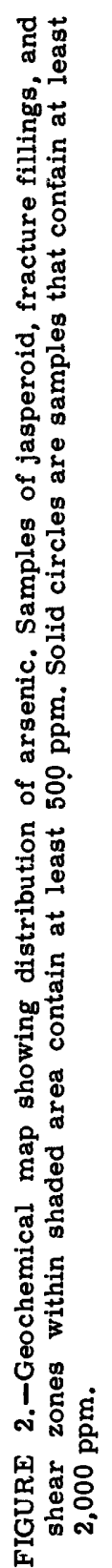




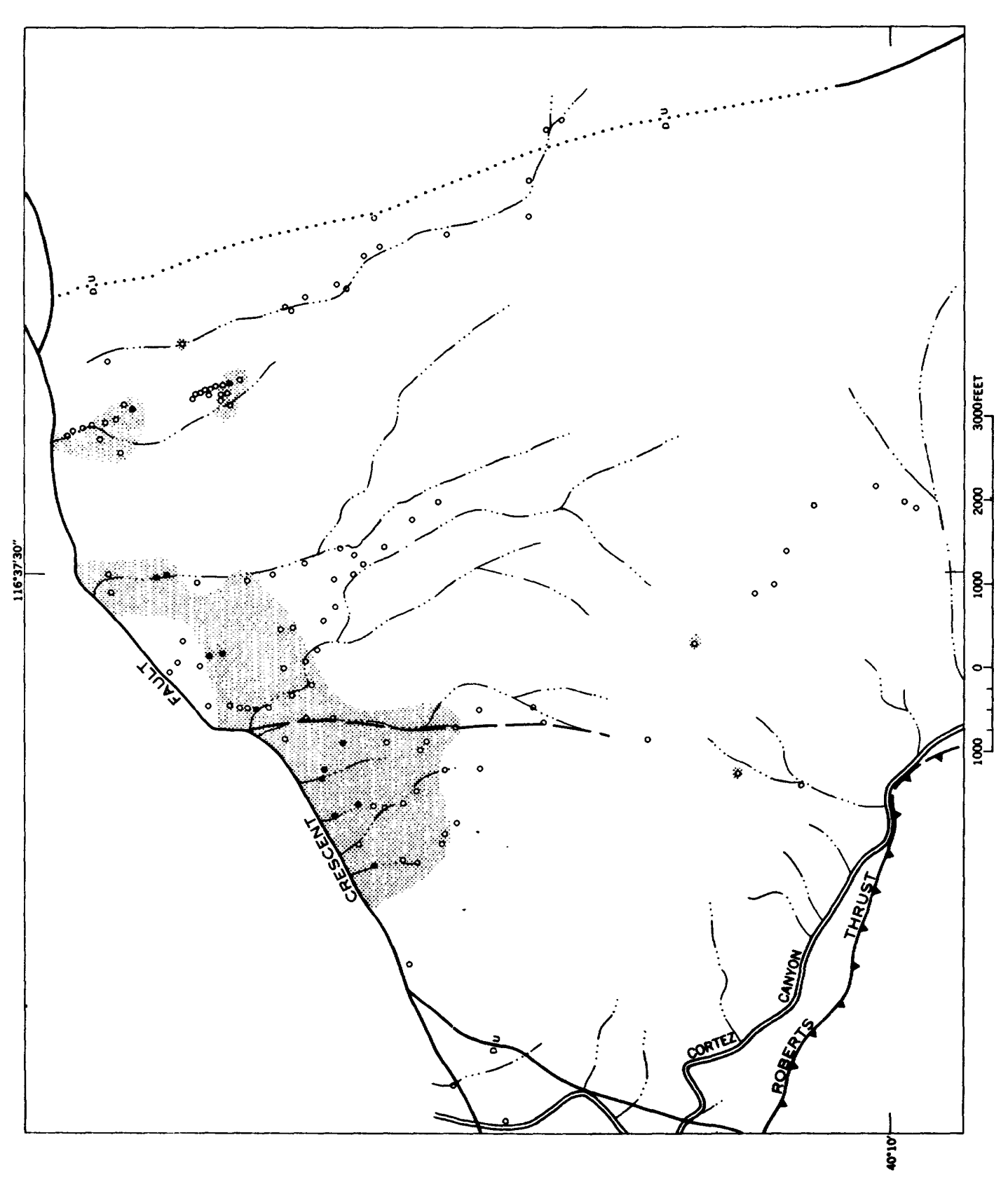

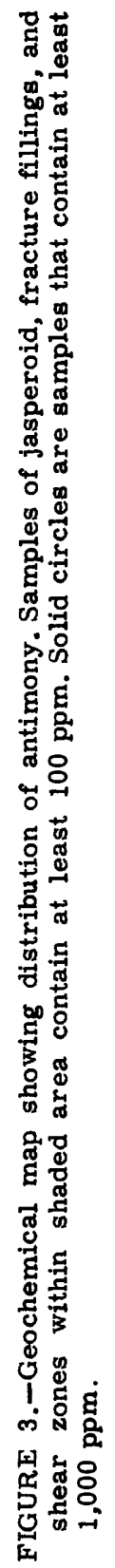




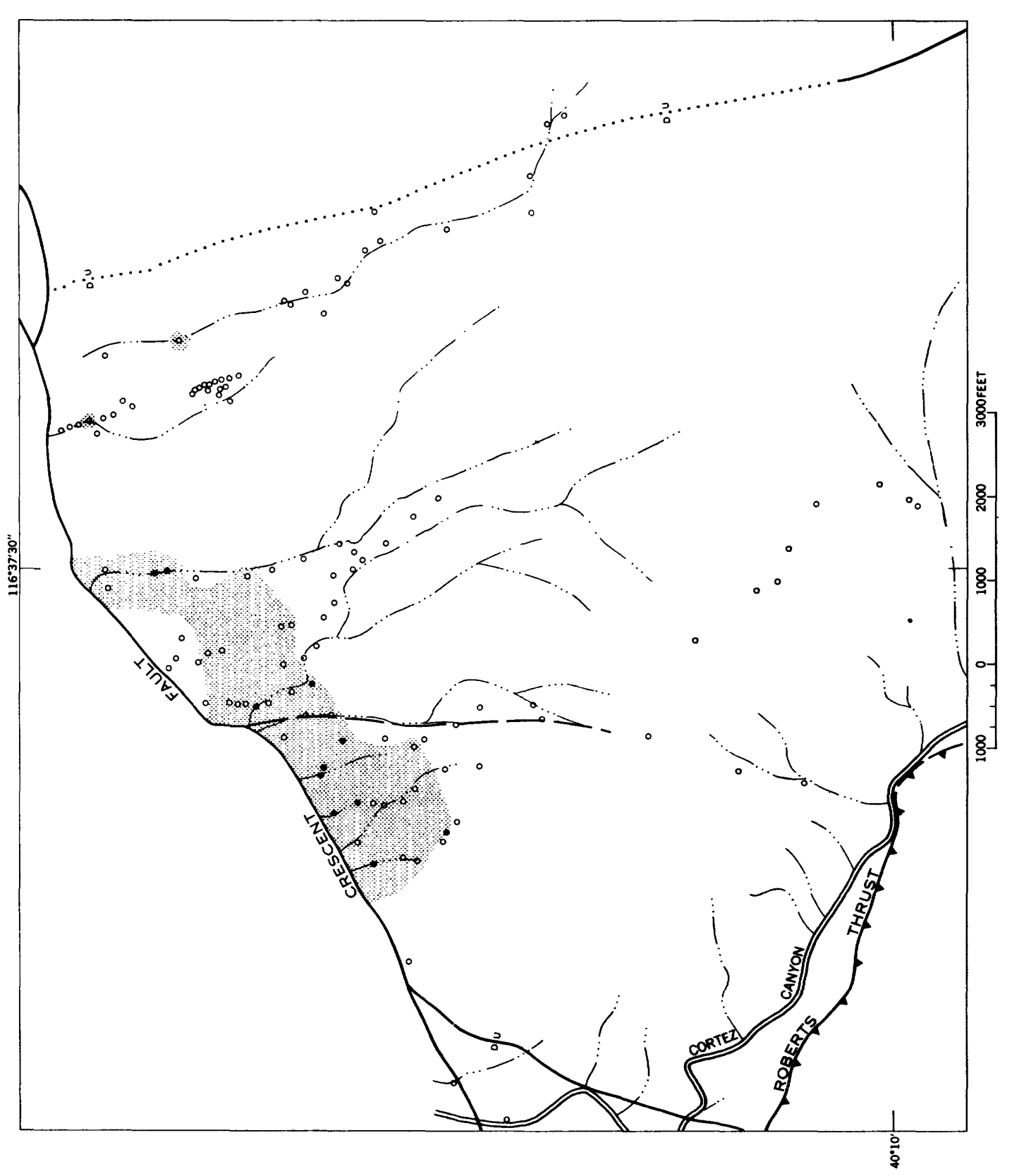

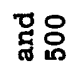

in

莺

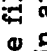

号 氶

.

4

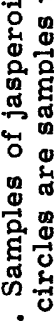

뭉

은

ङ

넝

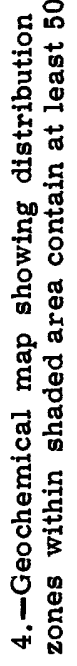

䁬

잉 


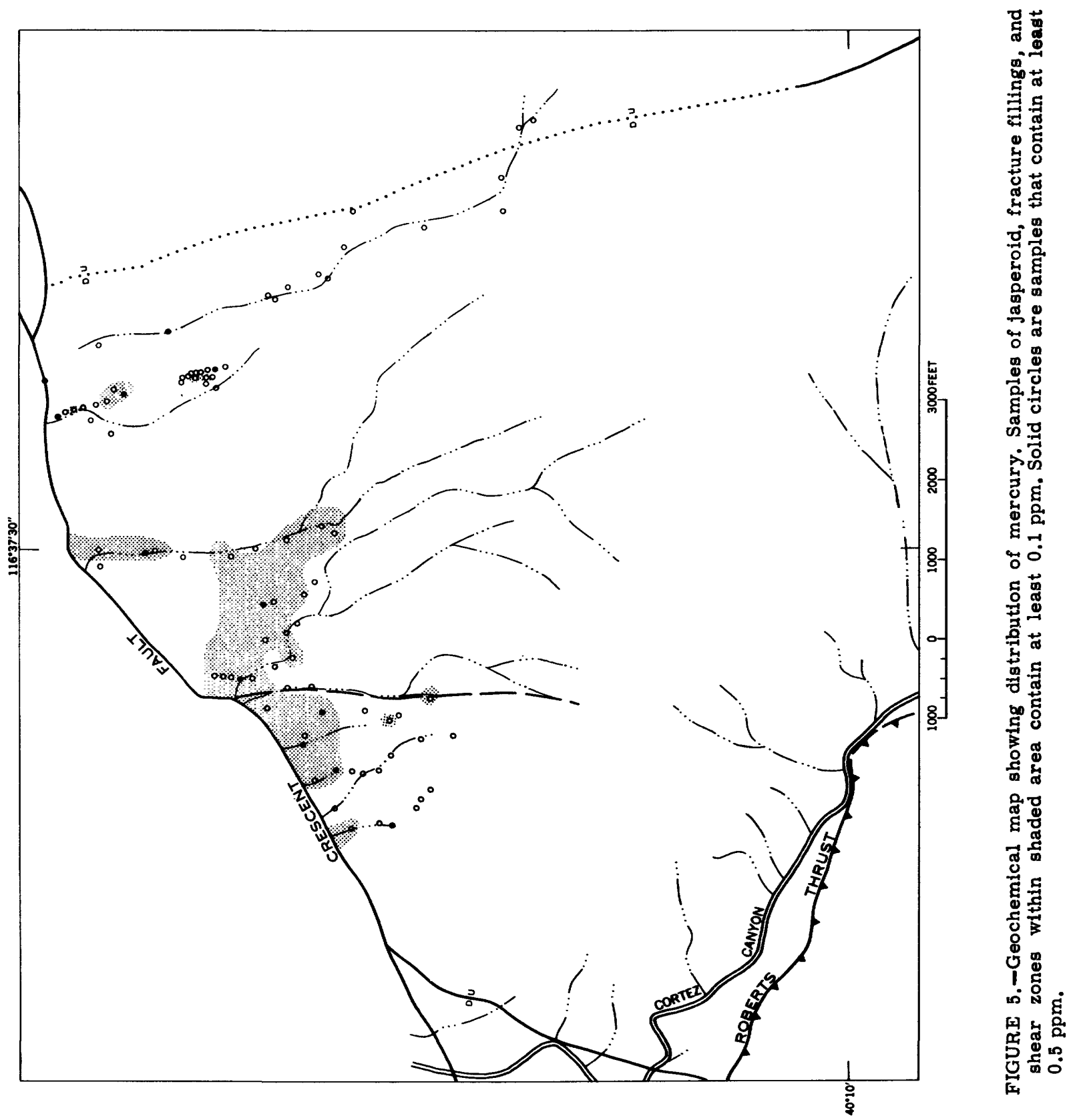

廿 U.S. GOVERNMENT PRINTING OFFICE : 1968 0-287-342 